\title{
Gambaran Tingkat Pengetahuan Dokter Jaga IGD tentang Penatalaksanaan Awal Sindrom Koroner Akut di Rumah Sakit Tipe C Se-Sumatera Barat
}

\author{
Annisa Dania Juliana ${ }^{1}$, M. Fadil ${ }^{2}$, Eka Fithra Elfi ${ }^{2}$
}

\section{Abstrak}

Sindrom koroner akut merupakan gawat darurat dari penyakit jantung koroner sehingga dibutuhkan penanganan yang cepat dan tepat dalam memberikan penatalaksanaan kepada pasien. Pengetahuan yang baik, dimulai dari diagnosis hingga penatalaksanaan awal kasus sindrom koroner akut baik pemberian obat-obatan maupun perlakuan tindakan, sangat penting dimiliki oleh seorang dokter jaga IGD dikarenakan akan mempengaruhi prognosis pasien. Tujuan penelitian ini adalah untuk mengetahui gambaran tingkat pengetahuan dokter jaga IGD tentang penatalaksanaan awal sindrom koroner akut di rumah sakit tipe $\mathrm{C}$ se-Sumatera Barat. Jenis penelitian ini adalah studi deskriptif dengan pendekatan survei. Pengambilan sampel dilakukan dengan metode cluster sampling pada beberapa kota dan kabupaten yang dianggap dapat mewakili wilayah Sumatera Barat. Sampel pada penelitian ini berjumlah 50 orang yang dipilih berdasarkan kriteria inklusi dan ekslusi. Penelitian ini menggunakan kuesioner yang sudah divalidasi untuk kemudian diisi oleh responden. Hasil penelitian didapatkan sebanyak $50 \%$ responden memiliki tingkat pengetahuan kurang, $44 \%$ berpengetahuan cukup, dan hanya $6 \%$ yang berpengetahuan baik. Simpulan penelitian ini adalah tingkat pengetahuan dokter jaga IGD di rumah sakit tipe C di Sumatera Barat dapat dikategorikan kurang.

Kata kunci: sindrom koroner akut, tingkat pengetahuan, dokter jaga IGD, rumah sakit tipe C

\section{Abstract}

Acute coronary syndrome is a condition is also known as a coronary heart disease's emergency that needs a fast and appropriate treatment. A good knowledge to diagnose or to manage an acute coronary syndrome using drugs or other treatments, is totally necessary to have as a doctor on duty in emergency room, in order to improve patient's prognostic. The objective of this study was to find out the representation of doctor on duty's knowledge about acute coronary syndrome's early treatment in type C hospitals in West Sumatera. This was a descriptive research using survey approachment. The samples were got by cluster sampling method in several hospitals in some cities and regencies, which believed could representate a whole area of West Sumatera. There are 50 peoples chosen as sampels based on inclusion and exclusion criterias. This research used questionnaire that had been validated and then filled by respondents afterwards. The result of this research is, $50 \%$ of respondents are lack of knowledge, while $44 \%$ others have enough knowledge, and only $6 \%$ have a good level of knowledge about acute coronary syndrome's early treatment. The conclusion is knowledge level of doctor on duty in emergency room at Type-C Hospitals' West Sumatera in categorize as "Lack of knowledge".

Keywords: acute coronary syndrome, level of knowledge, doctor on duty of emergency room, type C hospital.

Affiliasi penulis: 1. Prodi Kedokteran Fakultas Kedokteran

Universitas Andalas Padang (FK Unand), 2. Bagian Jantung dan Pembuluh Darah FK Unand/RSUP Dr. M. Djamil Padang.

Korespondensi :Annisa Dania Juliana email: annisadj321@gmail.com Telp: 082288591997

\section{PENDAHULUAN}

Sindrom Koroner Akut (SKA) merupakan salah satu manifestasi dari Coronary Artery Disease (CAD) yang pada tahun 2020 diperkirakan akan menjadi penyebab utama kematian di negara-negara industri 
dan berkembang. ${ }^{1}$ Sindrom Koroner Akut (SKA) adalah keadaan saat terjadinya gangguan aliran darah koroner parsial hingga total ke miokard secara akut dengan manifestasi klinis berupa Unstable Angina Pectoris (UAP), Non-ST segment Elevation Myocardial Infarction (NSTEMI), dan ST segment Elevation Myocardial Infarction (STEMI). ${ }^{2,3,4}$

Tingginya angka kematian dan perawatan rumah sakit masih menjadikan SKA sebagai suatu masalah kardiovaskular yang utama walaupun teknologi dalam ilmu medis untuk diagnosis dan penatalaksanaan penyakit ini sudah canggih. ${ }^{5}$ Setiap tahunnya, ada sekitar 7 juta kematian disebabkan oleh SKA dan Coronary Artery Disease (CAD). ${ }^{6} \mathrm{Di}$ kawasan Asia-Pasifik, SKA merupakan penyebab utama dari mortalitas yang terjadi, bahkan diperkirakan mencapai setengah dari beban kesehatan global. $^{7}$ Penatalaksanaan yang tepat, terutama saat awal akan mengurangi angka rawatan rumah sakit, mortalitas dan morbiditas pada pasien dengan SKA. ${ }^{8}$

Dokter jaga IGD adalah seorang dokter umum yang masih aktif, honorer atau volunteer yang ditetapkan oleh surat perintah kepala rumah sakit. Dokter ini bertanggung jawab dalam pelayanan medis di IGD selama dan atau diluar jam kerja. ${ }^{9}$ Dokter jaga IGD harus mempunyai STR dan SIP untuk bisa menjalankan praktik kedokteran di tempatnya bekerja. $^{10}$

Instalasi Gawat Darurat (IGD) adalah unit rumah sakit yang memberikan pelayanan pertama kepada pasien. Unit ini dipimpin oleh seorang dokter jaga dengan tenaga dokter ahli dan berpengalaman dalam menangani PGD (Pelayanan Gawat Darurat), yang kemudian jika dibutuhkan akan merujuk pasien kepada dokter spesialis tertentu atau rumah sakit yang ditingkat yang lebih tinggi. ${ }^{11}$ Prosedur pelayanan di IGD merupakan kunci awal pelayanan petugas rumah sakit dalam melayani pasien. Kualitas pelayanan ditentukan oleh baik atau tidaknya sikap, tanggung jawab dan kesigapan petugas dalam memberikan pelayanan kepada pasien. ${ }^{12}$ Oleh karena itu, sangat penting untuk meningkatkan kemampuan dokter terutama dokter jaga IGD dalam penanganan SKA di rumah sakit.

Saat menangani kasus SKA, dalam 10 menit pertama seorang dokter jaga IGD sudah harus melakukan tindakan-tindakan evaluasi awal untuk menegakkan diagnosis SKA sehingga dapat memberikan penatalaksanaan awal yang cepat dan tepat. Pengetahuan dokter jaga IGD sangat mempengaruhi prognosis seorang pasien SKA karena penatalaksanaan yang baik dalam periode emas, yaitu satu jam pertama akan sangat membantu menghindari mortalitas dan morbiditas. ${ }^{13}$ Penatalaksanaan awal untuk kasus SKA yang dilakukan di IGD rumah sakit secara umum adalah bed rest total, pemasangan IVFD (Intravenous Fluid Drip) dan pemberian obat-obatan yang biasa dikenal dengan MONACO (Morfin, Oksigen, Nitrat sublingual, Aspirin, dan Clopidogrel). ${ }^{14}$

Rumah Sakit Tipe C merupakan sarana pelayanan kesehatan umum tingkat kabupaten/kota yang mempunyai fasilitas dan kemampuan pelayanan medis 4 (empat) spesialistik dasar dan 4 (empat) spesialistik penunjang. ${ }^{15}$ Keempat pelayanan medis spesialistik dasar ini meliputi: IImu Penyakit Dalam, IImu Kesehatan Anak, Bedah dan Obstetri Ginekologi. ${ }^{16}$

Berdasarkan survei awal yang telah dilakukan, 7 dari 10 dokter jaga IGD di beberapa rumah sakit tipe C di Sumatera Barat mengaku tidak terlalu paham secara detil tentang alur penatalaksanaan awal untuk kasus SKA dikarenakan di rumah sakit tempat mereka bekerja, kasus SKA akan langsung dirujuk setelah berhasil didiagnosis dan tidak diberikan penatalaksanaan yang persis sama dengan apa yang dijabarkan PERKI dalam pedoman tatalaksana kasus SKA. Hal ini disebabkan karena tidak lengkapnya alat dan obat-obatan yang tersedia di rumah sakit tersebut. Oleh karena itu, penulis merasa tertarik untuk meneliti mengenai pengetahuan dokter jaga IGD tentang penatalaksanaan awal Sindrom Koroner Akut di Rumah Sakit Tipe C se-Sumatera Barat karena akan sangat mempengaruhi bagaimana pasien ditatalaksana.

\section{METODE}

Penelitian ini merupakan studi deskriptif dengan pendekatan survei untuk mengetahui gambaran tingkat pengetahuan para dokter jaga IGD tentang penatalaksanaan awal sindrom koroner akut di rumah sakit tipe $\mathrm{C}$ se-Sumatera Barat. Penelitian dilakukan dari bulan Oktober 2017 sampai Maret 2018 di rumah 
sakit tipe C di Sumatera Barat yang diyakini dapat mewakili keseluruhan rumah sakit tipe $\mathrm{C}$ yang ada di Sumatera Barat.

Populasi penelitian ini adalah semua dokter jaga IGD rumah sakit tipe $C$ se-Sumatera Barat. Sampel penelitian yang dipilih adalah dokter jaga IGD rumah sakit tipe $\mathrm{C}$ di Sumatera Barat yang dianggap dapat mewakili populasi penelitian yang memenuhi kriteria inklusi dan eksklusi. Pengambilan sampel dilakukan dengan metode cluster sampling, yaitu dengan cara mengambil sampel berdasarkan wilayah atau lokasi populasi oleh karena objek yang diteliti sangat luas dan jarak dan biaya yang terbatas. Jumlah dokter jaga IGD yang menjadi sampel dalam penelitian ini adalah 50 orang. Peneliti mengambil 10 kabupaten dan/atau kota di Sumatera Barat sebagai wilayah dari cluster, yang dalam hal ini adalah rumah sakit tipe C, yang dapat mewakili wilayah Sumatera Barat untuk kemudian diambil sampel berupa dokter jaga IGD di rumah sakit tipe $\mathrm{C}$ yang terdapat di wilayah tersebut. Kriteria inklusi subjek: dokter jaga IGD bukan spesialis di rumah sakit umum tipe $\mathrm{C}$ wilayah Sumatera Barat yang sudah memiliki SIP dan STR, yang terpilih melalui metode pengambilan sampel dan bersedia menjadi responden.

Data diperoleh dari kuisioner yang telah diisi oleh responden dan selanjutnya akan dianalisis dan disajikan dalam bentuk tabel.

\section{HASIL}

Tabel 1. Karakteristik dokter jaga IGD di rumah sakit tipe C se-Sumatera Barat

\begin{tabular}{lcc}
\hline \multicolumn{1}{c}{ Karakteristik } & f & $\%$ \\
\hline Usia & 16 & 32 \\
$\leq 25$ tahun & 34 & 68 \\
$>25$ tahun & & \\
Jenis Kelamin & 21 & 42 \\
$\quad$ Laki-laki & 29 & 58 \\
$\quad$ Perempuan & & \\
Lama kerja di IGD & & \\
$\quad \leq 3$ tahun & 48 & 96 \\
$\quad>3$ tahun & 2 & 4 \\
Keikutsertaan dalam Seminar & & \\
Kepelatihan Jantung & & 72 \\
$\quad$ Ada & 36 & 28 \\
\hline
\end{tabular}

Berdasarkan Tabel 1, dapat dilihat bahwa $68 \%$ responden berumur di atas 25 tahun dan didominasi oleh perempuan (58\%). Sebanyak 96\% responden baru bekerja di IGD dan dari keseluruhannya, 72\% responden sudah pernah mengikuti seminar kepelatihan jantung.

Tabel 2. Gambaran tingkat pengetahuan dokter jaga IGD rumah sakit tipe $C$ di Sumatera Barat

\begin{tabular}{ccc}
\hline Tingkat Pengetahuan & $\mathbf{f}$ & $\%$ \\
\hline Baik & 3 & 6 \\
Cukup & 22 & 44 \\
Kurang & 25 & 50 \\
\hline Total & 50 & 100 \\
\hline
\end{tabular}

Pada Tabel 2, dapat disimpulkan bahwa setengah dari responden (50\%), yang dalam hal ini adalah dokter jaga IGD di rumah sakit tipe $C$ di Sumatera Barat, memiliki tingkat pengetahuan yang kurang mengenai penatalaksanaan awal sindrom koroner akut.

\section{PEMBAHASAN}

\section{Karakteristik Responden}

Berdasarkan pengisian kuesioner oleh 50 orang responden yang merupakan dokter jaga IGD di rumah sakit tipe C di Sumatera Barat, hasil penelitian menunjukkan bahwa responden lebih banyak berumur di atas 25 tahun. Hal ini terjadi karena pendidikan tinggi kedokteran membutuhkan waktu yang cukup lama sehingga rata-rata, setelah dilakukan survei, lulusannya ketika mendapatkan gelar dokter sudah berumur 24 tahun. Setelah menyelesaikan pendidikan tinggi kedokteran, seorang dokter juga harus melaksanakan internsip di daerah yang sudah ditetapkan. Hal ini juga membutuhkan waktu satu tahun. ${ }^{17}$ Oleh karena itulah dokter yang sudah bekerja tetap di IGD rumah sakit kebanyakan berusia di atas 25 tahun karena sebelumnya harus melewati beberapa tahapan dahulu untuk kemudian bisa bertugas atau bekerja di rumah sakit.

Hasil penelitian menunjukkan bahwa sebagai dokter jaga IGD, perempuan lebih banyak daripada laki-laki. Walaupun hal ini tidak secara langsung berakibat kepada banyaknya dokter jaga perempuan, 
namun fakta ini dapat dijadikan data ilmiah yang mendukung hasil penelitian ini.

Dokter jaga yang baru lebih banyak bekerja dibandingkan yang sudah lama bekerja di IGD dapat dikaitkan dengan umur dari dokter jaga yang telah dijelaskan sebelumnya. Data yang didapatkan dari penelitian, kebanyakan dokter mulai bekerja secara tetap di usia 25 tahun dan rata-rata dokter jaga yang bekerja berusia 27 tahun sehingga dapat disimpulkan bahwa hal tersebut mengakibatkan lebih banyak dokter jaga yang masih baru bekerja dibandingkan yang sudah lama bekerja di IGD.

Sebagian besar dokter jaga sudah pernah mengikuti seminar kepelatihan jantung sebelumnya seperti Advanced Cardiovascular Life Support (ACLS). Pelatihan atau seminar kepelatihan akan mempengaruhi tingkat pengetahuan seseorang. Hal ini sesuai dengan yang dikemukakan oleh Bart bahwa pelatihan merupakan upaya meningkatkan pengetahuan, mengubah perilaku, dan mengembangkan keterampilan. ${ }^{18}$ Diungkapkan juga oleh Tanjung dalam bukunya "Manajemen Motivasi" bahwa pelatihan merupakan suatu proses belajar mengajar terhadap pengetahuan dan keterampilan tertentu serta sikap agar peserta semakin terampil dan mampu melaksanakan tanggung jawabnya dengan semakin baik, sesuai dengan standar. ${ }^{19}$

\section{Tingkat Pengetahuan Responden tentang}

\section{Penatalaksanaan Awal Sindrom Koroner Akut}

Hasil penelitian menunjukkan bahwa $50 \%$ dari responden memiliki tingkat pengetahuan yang kurang, $44 \%$ berpengetahuan cukup, dan hanya 6\% yang dapat dikategorikan memiliki tingkat pengetahuan yang baik. Hal ini berarti separuh dari responden tidak terlalu mengetahui bagaimana penatalaksanaan awal yang baik untuk kasus SKA, dimulai dari pengetahuan dalam mendiagnosis pasien dengan SKA hingga memberikan obat-obatan atau tindakan sebagai penatalaksanaan awal kepada pasien SKA yang dalam hal ini harus dilakukan di IGD rumah sakit.

Pertanyaan pada kuesioner ini meliputi diagnosis serta penatalaksanaan awal yang harus dilakukan pada kasus SKA, baik itu pemberian obatobatan maupun pemilihan tindakan invasif. Berdasarkan analisis yang didapat dari jawaban kuesioner, untuk pertanyaan mengenai penegakan diagnosis SKA (pertanyaan nomor satu sampai tiga), didapatkan data bahwa responden paling banyak salah pada pertanyaan nomor 1 . Sebanyak 22 orang dokter jaga keliru menjawab pertanyaan mengenai keluhan pasien berdasarkan anamnesis yang dilakukan oleh dokter sebagai salah satu poin penting dalam penegakan diagnosis definitif SKA. Oleh karena itu, maka diharapkan semua unsur yang bertanggung jawab akan kualitas seorang dokter baik itu institusi (perguruan tinggi tempat dokter tersebut belajar), rumah sakit (institusi tempat dokter tersebut bekerja), dan dokter itu sendiri, harus lebih memperhatikan kualitas pengetahuan para dokter jaga mengenai penegakan diagnosis SKA.

Berdasarkan analisis yang didapatkan dari jawaban kuesioner mengenai hal yang berhubungan dengan penatalaksanaan awal SKA, kesalahan yang banyak dilakukan responden adalah menjawab pertanyaan nomor 10, nomor 16, dan nomor 17 . Pertanyaan nomor 10 dijawab dengan benar hanya oleh enam orang responden saja, yang berarti 44 orang lainnya menjawab dengan salah. Pertanyaan pada kasus ini adalah mengenai pilihan utama untuk terapi nitrat dalam menatalaksana pasien SKA, yaitu pilihan dalam menggunakan isosorbid dinitrat (ISDN) atau nitrogliserin (NTG). Hal ini harus lebih diperhatikan oleh setiap dokter jaga serta rumah sakit dikarenakan amatlah penting untuk tahu pilihan utama dalam setiap terapi yang harus diberikan kepada pasien SKA. Hal ini juga tidak terlepas dari ketersediaan obat di rumah sakit yang bersangkutan karena setelah dilakukan wawancara dengan dokter ahli, dijumpai fakta bahwa ISDN jauh lebih mudah didapatkan dan tersedia lebih banyak dibandingkan NTG sehingga dokter jaga IGD lebih memilih ISDN dibandingkan NTG.

Pada pertanyaan nomor 16, sebanyak 43 responden tidak berhasil menjawab pertanyaan dengan benar, yang artinya hanya tujuh orang responden yang menjawab dengan benar pertanyaan tersebut. Pertanyaan ini mengenai kapan dan mengapa strategi invasif segera atau urgent harus dilakukan. Para responden kebanyakan keliru dalam memahami perbedaan antara pemberian strategi invasif segera (urgent) dan strategi invasif awal (early). 
Hal ini juga berkaitan dengan pemahaman mengenai perbedaan antara kategori risiko sangat tinggi (very high risk) dan risiko tinggi (high risk). Dibutuhkan pemahaman yang lebih baik oleh para dokter jaga agar dapat membedakan kategori tersebut dengan lebih baik.

Pada pertanyaan nomor 17 , sebanyak 34 responden menjawab keliru pertanyaan yang diajukan. Hal ini mengenai berapa lama batas waktu yang diperbolehkan untuk menatalaksana pasien mulai dari kontak medis pertama hingga perekaman EKG pertama. Permasalahan ini menjadi sangat perlu diperhatikan sebab prognosis pasien pada kasus SKA sangat ditentukan oleh waktu. Semakin lama waktu yang terbuang atau dihabiskan tanpa penatalaksanaan yang baik, maka semakin buruk prognosis pasien karena semakin luas area yang mengalami infark.

Pengetahuan dapat mempengaruhi seorang dokter dalam mengambil keputusan mengenai hal yang harus segera dilakukan serta yang tidak boleh dilakukan. Pengetahuan yang kurang dari seorang dokter jaga IGD akan mempengaruhi dokter tersebut dalam mengambil keputusan untuk menatalaksana pasien. Pada akhirnya, hal itu juga akan mempengaruhi prognosis dari pasien tersebut. Oleh karena itu, upaya untuk meningkatkan pengetahuan dokter jaga IGD di setiap rumah sakit sangat penting dilakukan dengan baik dan sungguh-sungguh. Pengkajian lebih lanjut mengenai factor yang mempengaruhi pengetahuan dokter jaga mengenai penatalaksanaan awal SKA juga penting untuk dilakukan.

\section{SIMPULAN}

Tingkat pengetahuan dokter jaga IGD tentang penatalaksanaan awal sindrom koroner akut di rumah sakit tipe C di Sumatera Barat dapat dikategorikan kurang.

\section{DAFTAR PUSTAKA}

1. Bassand JP, Hamm CW, Ardissino D, Boersma E, Budaj A, Fernandez-Afilles $F$, et al. Guideline for the diagnosis and treatment of non-ST segment acute coronary syndrome. Eur Heart J. 2007 Jul;28(13):1598-660.
2. Rilantono LI. 5 rahasia penyakit kardiovaskular (PKV). Jakarta: Badan Penerbit Fakultas Kedokteran Universitas Indonesia; 2015.

3. Antman EM, Braunwald E. Harrison's Principle of Internal Medicine. Edisi ke-17. Amerika Serikat: McGraw-Hill; 2008.

4. Cannon CP, Kumar A. Acute Coronary Syndromes: Diagnosis and Management, Part II. Mayo Clinic Proceedings. 2009; 84(11):1021-36.

5. Hamm CW, Bassand JP, Agewall F, Bax J, Boersma $\mathrm{E}$, Bueno $\mathrm{H}$, et al. ESC guideline for the management of acute coronary syndromes in patients presenting without persistent ST-segment elevation. Eur Heart J. 2011 Des; 32(23): 29993054.

6. World Health Organization (WHO). The top ten causes of death. [serial online] 2017 Jan (diunduh 25 Oktober 2017). Tersedia dari http://www.who.int/news-room/fact-sheets/detail/ the-top-10-causes-of-death

7. Ohira T, Iso H. Cardiovascular disease epidemiology in Asia: an overview. Circ J. 2013; 77(7):1646-52.

8. Kolansky DM. Acute coronary syndromes: morbidity, mortality, and pharmacoeconomic burden. The American Journal of Managed Care. 2009;15(2 suppl):S36-41.

9. Rumah Sakit Umum Elim Rantepao. Standar prosedur operasional dokter jaga dokter umum. Bandung: Rumah Sakit Umum Elim Rantepao; 2014.

10. Sekretariat Negara RI. Undang-undang no. 36 tahun 2014 tentang tenaga kesehatan. Jakarta : Sekretariat Negara RI; 2014.

11. Hidayati H. Standar pelayanan kesehatan pasien IGD di rumah sakit umum Abdul Wahab Sjahranie Samarinda (skripsi). Samarinda: Fakultas IImu Sosial dan IImu Politik Universitas Mulawarman; 2014.

12. Kementerian Kesehatan RI Direktorat Jendral Pelayanan. Prosedur pelayanan di instalasi gawat darurat (IGD) rumah sakit. Jakarta: Ditjen Yanmed Depkes RI; 2006.

13. Perhimpunan Dokter Spesialis Kardiovaskular Indonesia. Pedoman tatalaksana sindrom koroner akut. Edisi Ke-3. Jakarta: Centra Communications; 2015 
14. Perhimpunan Dokter Spesialis Kardiovaskular Indonesia. Panduan praktis klinis (PPK) dan clinical pathway (CP) penyakit jantung dan pembuluh darah. Edisi ke-1.Jakarta: Centra Communications; 2016.

15. Departemen Kesehatan RI Sekretariat Jenderal Pusat Sarana, Prasarana, dan Peralatan Kesehatan. Pedoman teknis sarana dan prasarana rumah sakit kelas C. Jakarta : Depkes RI; 2007.

16. INA CBG'S. Syarat rumah sakit umum tipe C.
Informasi INA CBGs, BPJS, JKN dan Kesehatan Indonesia; 2015.

17. Kementerian Kesehatan RI. Peraturan menteri kesehatan Indonesia no. 39 tahun 2017 tentang penyelenggaraan program internsip dokter dan dokter gigi Indonesia. Jakarta : Sekretariat Kabinet $\mathrm{RI} ; 2017$.

18. Bart S. Psikologi kesehatan. Jakarta: PT Grasindo; 2004.

19. Tanjung H. Manajemen motivasi. Jakarta: PT Grasindo; 2004. 